\title{
Archaeology And The Print Media In Nigeria
}

\author{
${ }^{1}$ Obinna F. Emeafor; ${ }^{* 2}$ Cynthia Ijeoma, Emeafor \& ${ }^{3}$ Eileen Chioma, Ezinwa \\ ${ }^{1}$ Department of Archaeology and Tourism, University of Nigeria, Nsukka. \\ ${ }^{2}$ Department of Mass Communications, Coal City University, Enugu \\ ${ }^{3}$ Deparment of Mass Communication, Madona University, Okija \\ Corresponding author: cynthiaemeafor@gmail.com
}

\begin{abstract}
Archaeology examines human cultural expressions as reflected in the artefactual record, in particular, through excavation of the remains of human settlements. Problems with Archaeology in Nigeria have been viewed in terms of poor funding, low number of archaeologists, and poor preservation of artifacts. The reportage and/or framing of Archaeology and archaeological issues by the Nigerian print media are other factors to be considered in discussions about the problems with Nigerian Archaeology. This holds true because effective and frequent reportage on archaeological issues will no doubt influence the way people perceive Archaeology. Consequently, the paper examined how two print media outfits - The Guardian and Vanguard newspapers frame issues on archaeology from $1^{\text {st }}$ May 2019 to $31^{\text {st }}$ July, 2019. The investigation laid much emphasis on frequency, prominence, story type and frame used in the reportage. Findings revealed that the newspapers recorded only 7 news stories within the study period, and all the reports were placed inside the pages of the sampled newspapers. Result also revealed that news was used mainly to report issues on archaeology and related issues such as arts and culture for extant society, travel and tourism were reported more than archaeological issues. The implication of the findings is that archaeological issues were accorded low priority in the sampled newspapers. Based on the findings, the study recommends that archaeology and archaeological issues should be reported frequently using other formats - editorial, feature and opinion articles for in-depth analysis, and for better understanding of the importance of Archaeology to society.
\end{abstract}

Keywords: Archaeology, Print Media, Newspapers, Reportage, Nigeria

DOI: $10.7176 / \mathrm{NMMC} / 99-04$

Publication date:November $30^{\text {th }} 2021$

\section{Introduction}

Archaeology is the systematic study of human societies, especially prehistoric or extinct societies through the remains of their material culture. In the view of Winthrop (1991 p.13), Archaeology examines human cultural expression as reflected in the artefactual record, in particular through the excavation of the remains of human settlements. It seeks to document both the specific cultural patterns of past human groups and the broad shifts in the scale, complexity, and adaptation of human societies manifested over the entire archaeological record.

Folorunso (2011) tells us that the historical development of archaeology in Nigeria could be traced to the first digs at Ile Ife in 1910 by the German anthropologist, Leo Frobenius, who searched for buried terracotta figurines, to the accidental discovery of the first piece of what have become known as the Nok terracotta figurines in tin mines on the Jos Plateau in 1928, and finds of archaeological materials in the course of digging foundations in Benin, Ife and Igbo-Ukwu in 1938.

In Nigeria of today, however, Archaeology, whether as a discipline of human knowledge or as a phenomenon, appears to be a low priority area. In fact, the entire domain of culture and cultural heritage are relegated to the background in the scheme of things. This is a most unfortunate situation and equally, suggests that Nigeria as a nation is yet to come to terms with the significance of Archaeology in human existence and nation-building. 
A handful of writers have articulated the problems with Nigerian Archaeology. Ogundele (1995), for instance, identified funding, low number of archaeologists, climatic condition (humid topical region) which makes it difficult for the survival of archaeological data such as bones and wooden artefacts, etc. Another problem which, perhaps, has not gained much attention is the framing of Archaeological issues in Nigerian print media. Eck (2014) remarks that ever since the modern science of archaeology began to develop from its earlier antiquarianism, there has been a role for the media - from book publishing to newspaper journalism's coverage of discoveries to the depiction of archaeology in various visual arts - in shaping both the profession's and the public's awareness and desire to preserve the world's archaeological and cultural heritage.

For the fact that the media are effective instrument of disseminating information, socialization, integration, mass mobilization, and cultural promotion, etc, the media are equally expected to promote archaeological concerns in Nigeria. As noted by Nwabueze, et al. (2015), the media have the responsibility of setting agenda and shaping the way the public understand issues, their impact and the need for action. Based on the foregoing, the reportage and/or framing of Archaeology and archaeological issues by the Nigerian print media can determine the extent of value accorded to the practice of Archaeology, since effective and frequent reportage on archaeological issues will no doubt influence the way people perceive archaeology.

Deriving from the aforesaid, the cardinal aim of the paper was to examine how two print media outfits The Guardian and Vanguard newspapers - frame issues on Archaeology. The investigation laid much emphasis on frequency, prominence and contents of the reportage. The specific objectives of the study were:

1. To determine the frequency in the coverage of archaeological issues in The Guardian and Vanguard Newspapers.

2. To ascertain the prominence given to Archaeology in Nigeria in the selected newspapers.

3. To identify the story type used in the coverage of archaeology and other issues reported.

4. To ascertain the frames used to represent issues on archaeology.

\section{Literature Review}

As remarked by Kumar (2009), "Communication is an integral part of human civilization and culture". When communication is meant to reach large audiences, mass media is readily available to achieve that purpose. Mass media refers to all of the communications media that reach a large audience, especially television, radio, and newspapers (Microsoft Encarta, 2009). The mass media are divided into two broad categories: electronic media and print media. The print media, as an aspect of mass media, is a way of communicating to the public (mass communication) which relies on the use of printed publications such as newspapers, magazines, flyers, among others.

Several studies have been conducted on the role of the media in the preservation of indigenous cultures and cultural heritage. Empirical study by Romanova, Yakushenkov and Lebedeva (2013) indicated that the media, through information and entertainment functions, preserve the memories of the past, the roots of a culture, the nature and the real shape of the objects of cultural heritage. Iheanacho (2014) investigated media role on cultural education, acculturation and diffusion. The findings of the study revealed that purveyance and eulogy of cultures, bridging cultural gap between the archetypal age and the contemporary time, promoting cultural globalization and acculturation are the major roles the media play. 
Rukya (2016) in her own study observed that the indigenous cultures are promoted through the mass media owned by the government and private bodies as well as the social media of the cyberspace. The study recommended that more efforts should be added to prevent the cultural values from being swallowed by the pop culture of the Western world that control the media at large. In similar vein, Simon and Ndoma (2016) looked into Nigerian media and indigenous cultures transformation to find out how far the media have gone. They observed that the Nigerian media have resorted to promoting, developing and emphasizing western culture in its entirety, while relegating and dabbing Nigeria culture. Finally, from the perspective of indigenous film production such as the Nollywood, Danbello and Dakogol (2016) found that the Nigerian film industry has failed to preserve the great heritage of Nigerians. The study suggests that for easy identification in the globe, Nigerian film makers must make every effort in the preservation of Nigerian culture.

Print media and mass media in general are deemed very important in the preservation and promotion of archaeological heritage. Brittain and Clack (Eds.) (2007) are of the view that Archaeology's use of the media for securing archaeological futures is by no means new. Eck (2014) remarks that ever since the modern science of archaeology began to develop from its earlier antiquarianism, there has been a role for the media - from book publishing to newspaper journalism's coverage of discoveries to the depiction of archaeology in various visual arts - in shaping both the profession's and the public's awareness and desire to preserve the world's archaeological and cultural heritage.

McManamon in Stone and Molyneaux (1994 p.67) are of the view that positive mass media messages may awaken interest in the study of archaeology, and such interest may be served in a variety of different ways and at different levels. People can read books or newspapers or journal articles about archaeological sites, excavations, or other archaeological subjects. They noted that in most of the United States, there are state-wide archaeological organizations, these organizations publish a quarterly journal about archaeological investigations and research results within the State. The coverage is often detailed and technical, but these publications provide interested readers with a general up-to-date view of the American archaeology scene (McManamon in Stone and Molyneaux (Eds.) 1994 Pp.67-68).

On the contrary, Henson (2005 p.1) in Wegdam (2015) opines that the attention mass media gives Archaeology is not always well-received by the discipline itself. Some archaeologists claim mass media misrepresents Archaeology (Clack and Brittain 2007 p.16; Stern and Tode 2009 p.17), which can cause the public and funders to develop unrealistic expectations about the way archaeology should be practiced, which in turn can lead to an actual change in the way it is practiced.

Be that as it may, it is easy to see that adequate reportage of archaeological issues in Nigeria can go a long way to reawakening interest in archaeological heritage and the need to jealously guard them for research, education, tourism and sustainable development. As a starting point, there is the need to ascertain the level and nature of reportage of archaeology and archaeological related issues in Nigeria, so as to see how reportage can be consolidated where the level is encouraging as well as how reportage can be given a significant boost where it is low. 


\section{Theoretical Framework}

Social Responsibility Theory (SRT) was used as the theoretical framework for the study. The theory places emphasis on the moral and social responsibility of persons as well as institutions which operate the mass media (Naji, 2012). In other words, the theory states that the mass media should permeate and represent all the strata of the society (Stephen, 2014). Studies by Igbinoba (2008); Akpor and Clever (2016); William, Layefa and Taiwo (2016) all affirmed that the media must have social conscience, be devoted to public welfare and public service; they should be responsive to problems in the society. Following from the aforesaid, it becomes easy to conclude that the Nigerian mass media, in this case the print media, should frequently report issues on archaeology by providing several media contents through accurate and objective reports.

\section{Materials and Method}

The approach to the study was content analysis. Wimmer and Dominick (2011) note that this research approach evaluates communication in a systematic, objective, and quantitative manner for the purpose of measuring variables. The method was found appropriate as it involves examination of the manifest contents of newspapers in relation to issues on archaeology in Nigeria. Two Nigeria newspapers: The Guardian and Vanguard were purposively selected for this study because of their accessibility and availability.

The study universe consists of editions of The Guardia and Vanguard newspapers published from 1st May to July $31^{\text {st }}$; 2019. This covers a period of three months. The reason behind this choice was because the media, in carrying out their social responsibility role at any point in time, ought to report issues on archeology.

The universe of the study was made up of the number of editions of newspapers that make up the three months multiplied by two gives the total of 182 (i.e.91x $2=182$ ) editions. The researchers used census sampling technique to determine the sample size. This means that all the 182 editions published by the two newspapers (The Guardian and Vanguard, i.e.91 editions each) were analyzed.

The units of analysis include the following: News, Features, Editorials, and Opinions. Under each of the units of analysis, the following were the content categories:

* Frequency (number of times each unit of analysis appeared)

* Prominence (using Front page, Back page and Inside page)

* Source of news (using News, Editorial, feature and Opinion)

* Frames (Treasure and empowerment, Reincarnation and Heritage)

SPSS version 20.0 was used to analyze the frequency and simple percentages of the data generated in the course of this research, while results were presented using tables and charts.

\section{Result}

This section presents findings for the study period - $1^{\text {st }}$ May to July $31^{\text {st. }}$ 2019. A total of 91 editions of each of the two newspapers studied from The Guardian and Vanguard making a grand total of 182 editions were analyzed. Out of the 182 editions analyzed, only 6 editions of the newspapers from the two newspapers published news stories on archaeology in Nigeria. In all, a total of 7 reports on archaeology in Nigeria were obtained out of the 182 editions of newspapers studied. The results are shown below. 
Fig. 1: Frequency distribution of reports in The Guardian and Vanguard newspapers

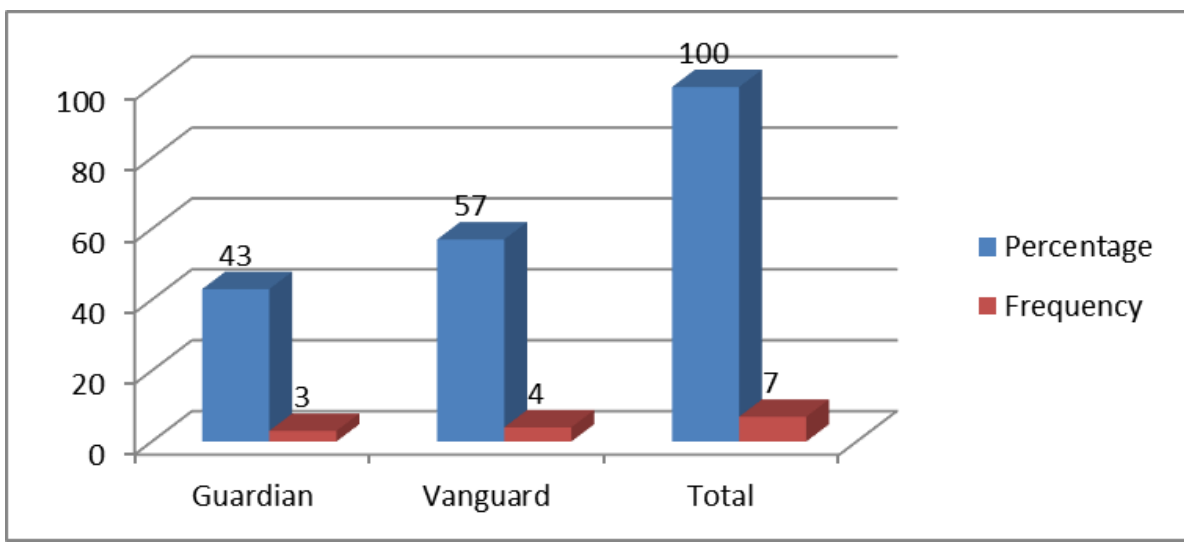

From table 1, The Guardian had 3(43\%) reports on archaeology in Nigeria. On the part of Vanguard, it had $4(57 \%)$ reports. The implication is that with the little reports published on archaeology by the two newspapers, Vanguard had more reports as when compared with The Guardian newspaper.

\section{Fig.2: Data distribution based on prominence}

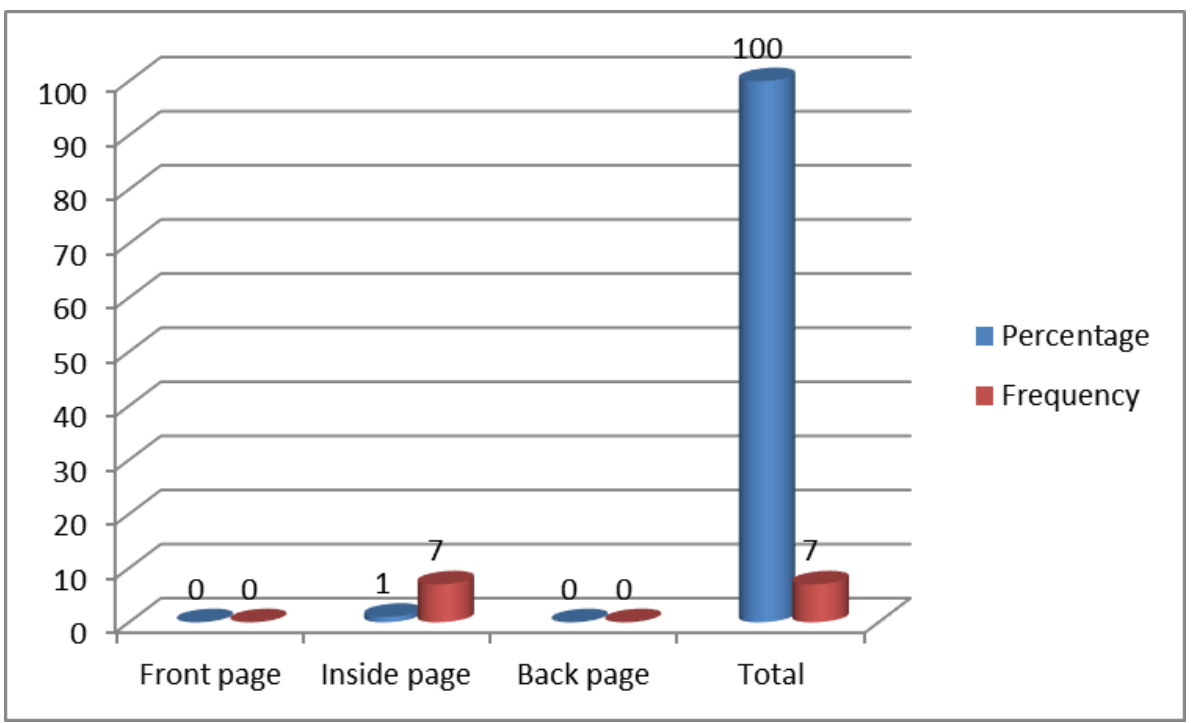

Fig. 2 shows the frequency and percentages of reports on archaeology based on prominence. From the figure, all the 7 reports with $(100 \%)$ appeared inside the pages while Front and Back page presented no story on archaeology in Nigeria. This indicates that the two newspapers - The Guardian and Vanguard presented the reports on archaeology only inside the pages of the newspapers sampled. 


\section{Fig. 3: Distribution of data based on story type}

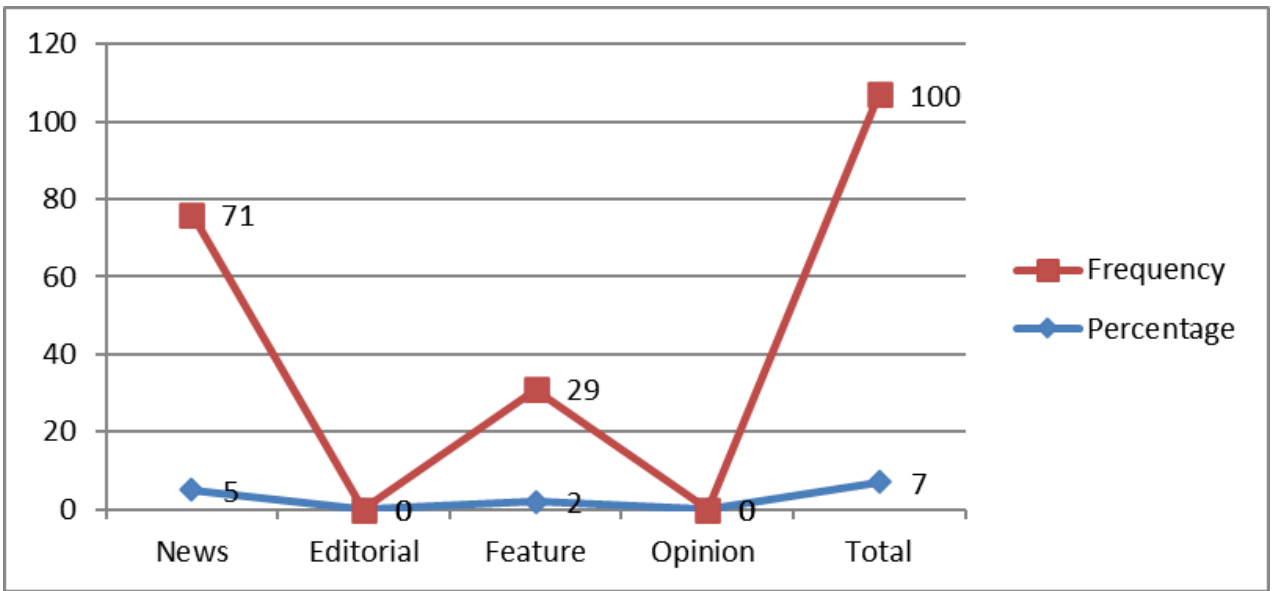

Fig.3 shows that 'news' featured 5 times with (71\%), feature articles presented 2 (29\%) stories. Editorial and opinion article recorded no story on archaeology in Nigeria. The implication is that the two newspapers, that is, The Guardian and Vanguard presented the reports on archaeology in Nigeria using mainly the news format.

\section{Fig.4: Distribution based on the frames}

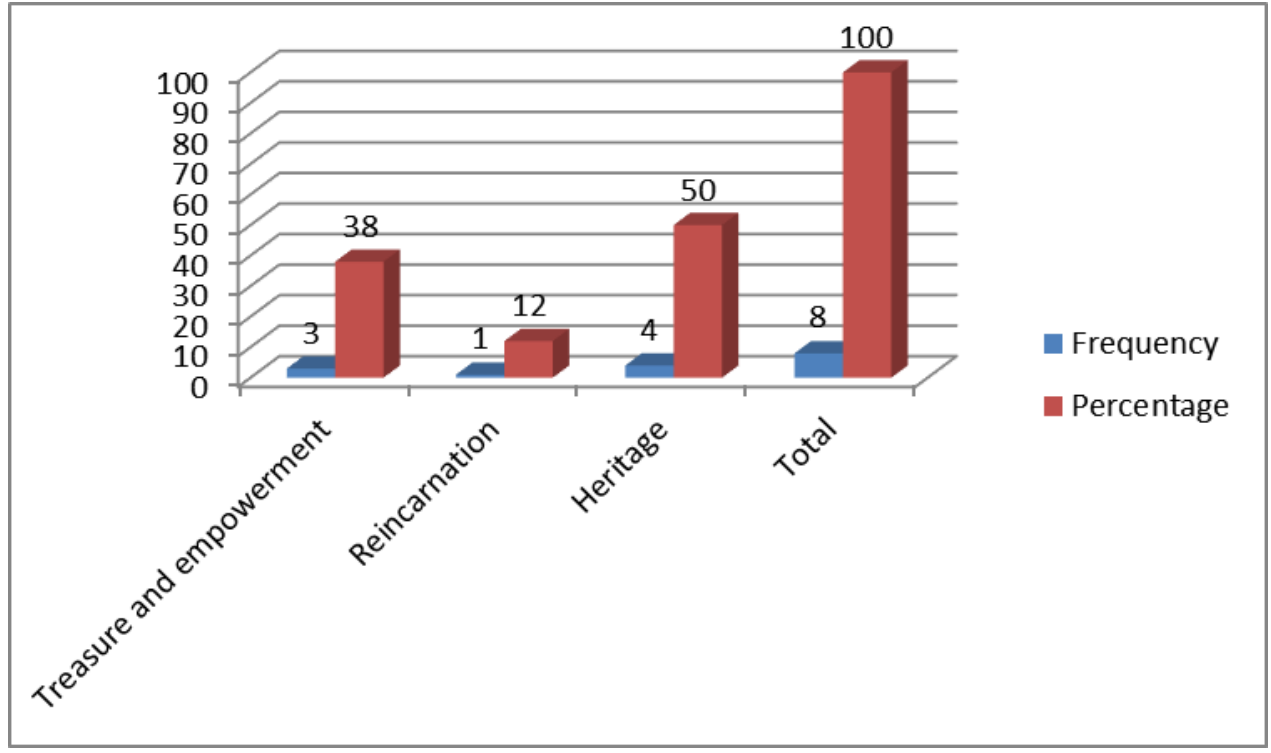

Fig. 4 shows frequency and percentages of frames used by The Guardian and Vanguard newspapers to represent archaeological issues. In the Fig., In Treasure and empowerment recorded 3(38\%); 1(12\%) were devoted to Reincarnation while Heritage had the highest with 4 (50\%) frames. 
Fig.5: Distribution based on other issues

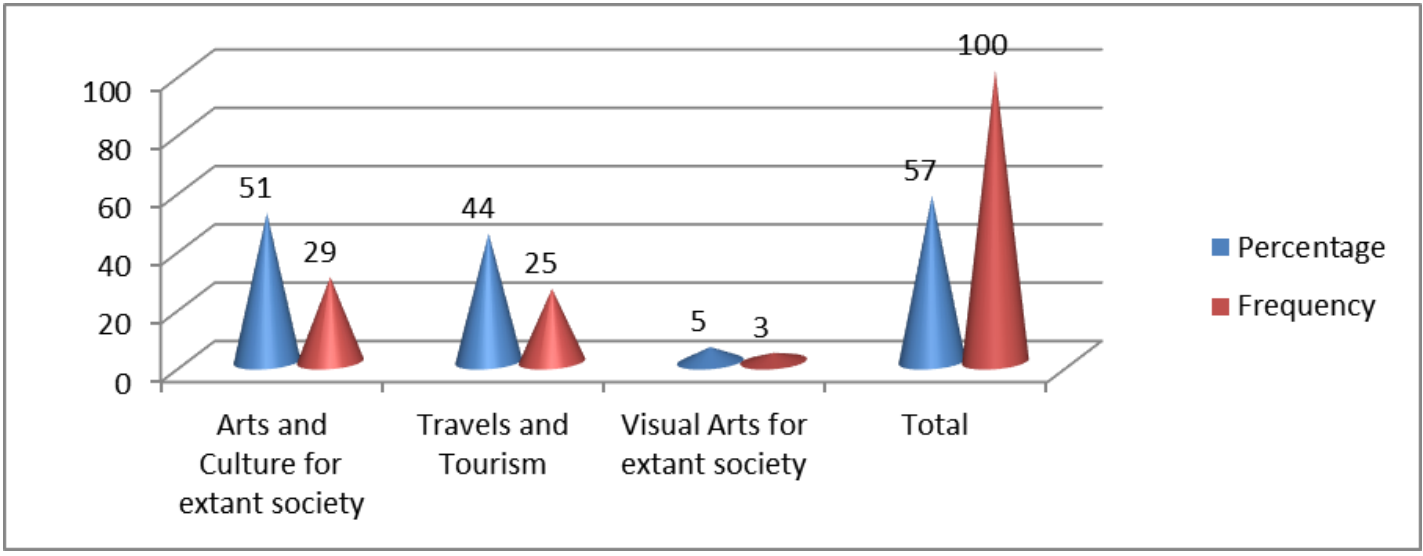

From the fig above, it can be observed that other issues such as Arts and Culture for extant society appeared 29 (51\%) times; Travel and Tourism featured 25 (44\%) while Visual Arts for extant society had 3 $(5 \%)$. The implication of this result is that the two newspapers had more stories on other issues than archaeological issues.

\section{Discussion}

The result obtained from the data analysis in relation to the proportion of news stories on archaeology across three months of study show that the two selected newspapers: The Guardian and Vanguard gave little attention to issues on archeology. It important to note that the number of times an issue is reported over other matters relates of its importance or value and as such, gives the readers a clue to its significance. As regards research objective 1, the result from the analysis of the data in Fig.1 shows vividly that the selected newspapers did not give sufficient coverage to archaeology within the period of study. Only 7 stories on archeology were gathered out of 182 editions of newspapers studied. This implies that issues on archaeology are not regarded as crucial as other issues reported. This is an indication that issues on archaeology are handled with levity. Issues on archaeology ought to be reported frequently by the media, particularly the print media, for the public to know more about Nigerian archaeological heritage. The result also shows that the two newspapers did not adequately carry out their social responsibility role in capturing stories on archaeology in Nigeria.

As regards the prominence in Fig.2, it was observed that majority of the reports on archaeology were positioned inside the pages (100\%) of The Guardian and Vanguard newspapers. None of the story appeared on the Front page or Back page of the newspapers. This indicates that news stories on archaeology are still seen as less important to feature at the front page or back page of the sampled newspapers. Placement or prominence, as stated by Aniekeme (2016) shows how much importance the editor attaches to a news event and one of the ways to gauge the importance the newspapers attach to news stories is to look at where the stories were placed. Iroko (2016) corroboratively note that in making decisions for the placement of stories, editors are inevitably communicating to readers which issues and corresponding stories should receive the most attention. Linking this finding to the social responsibility model suggests that the mass media should permeate and represent all the strata of the society (Stephen, 2014); it was observed that the sampled newspapers did not execute their social responsibility function very well. 
Looking at the story type (genre), it was observed that the two newspapers used mainly the news format to report stories on archaeology in Nigeria. This implies that The Guardian and Vanguard newspapers reported issues on archaeology as they occurred without in-depth explanations of the issues using other format of news presentation. As can be seen in Fig. 3, feature article recorded low reports. It should be noted that feature articles go beyond the straight news presentation by providing background informative stories on issues on archaeology to the public. By reporting complex issues through feature, opinion articles and editorial, in-depth interpretations of the issues are provided for public understanding.

Furthermore, it was observed that for the period of the study, the two newspapers under study focused mainly on other issues apart from issues pertaining to archaeology. These issues are arts and culture, visuals arts for extant society, travels and tourism. These issues focused more on things that have to do with the extant population. This is evident in the report presented by vanguard newspaper on page 14 of July $19^{\text {th }}, 2019$ with the headline: Medical Tourism: Lagos unveils criticare unit to manage brain, kidney problems. Another story was published by The Guardian on May $13^{\text {th }} 2019$ on page 37 with the heading: Arts, Culture Contents of Tourism. In fig. 1, it was observed that only 7 stories were recorded by The Guardian and Vanguard on issues regarding archaeology, while other issues as stated above recorded more news stories as can be seen in Fig.5. Archaeological issues such as abandoned settlements, stone tools, cultural landscapes, conservation of artifacts, public archaeology, excavation and the general poor practice of archaeology, etc ought to be given proper reportage for greater preservation of archaeological heritage and improved understanding of the relevance of archaeology by the public.

Additionally, it was observed from the data that archaeological issues were framed using heritage, reincarnation, treasure and empowerment in The Guardian and Vanguard newspapers. This shows that archaeological issues interpreted as heritage which has to be preserved for posterity. This is evident in the news report by The Guardian on page 31, July14 ${ }^{\text {th }}, 2019$ with the headline: Akure set to host Soyinka, Fagunwa, and Yoruba artistic Heritage conference. Another story was reported by vanguard newspaper on page 34 of June $22^{\text {nd }}, 2019$ with the heading: Masquerade: When ancestors visit the living. Tears and joy of Egungun Festival.

\section{Conclusion and Recommendation}

The study clearly shows that there is low reportage of archaeology and archaeological issues in the two newspapers within the duration under focus. This is very worrisome and suggests that archaeology as both a phenomenon and a discipline of human knowledge has not benefited much from the agenda setting role of the media, in this case, the print media. The result is that issues on Archaeology were not well-projected to the public within the period of study. This pathetic situation, perhaps, may well extend beyond the time frame covered by the study.

The low priority status of archaeology in the print media as suggested by this study is very much akin to the peripheral stance of culture and cultural heritage (archaeological heritage inclusive) in Nigeria's scheme of things (see, for example, Kimbers, 2006). One of the biggest mechanisms through which archaeological heritage and heritage in general could be given proper recognition is through the media. Thus, it is very imperative that the Ministry of Information and Culture, together with its agencies, should make serious attempt at convincing 
the media to channel more efforts towards the promotion of archaeological heritage as part of the resources needed for sustainable development and nation-building. Conclusively, the study recommends that:

1. The Nigeria press should give more prominence for more emphasis on issues on archaeology through front page news stories, editorials, and feature and opinion articles for better understanding of the importance of archaeology by the public.

2. There should be frequent reports on archeological issues by the press. This will go a long way to helping readers know the importance of preserving archaeological heritage for posterity, tourism development and research purposes.

3. National Commission for Museums and Monuments (NCMM) should develop deeper partnership with the print media which will provide the synergy for more in-depth reportage of archaeological issues in Nigerian print media.

\section{References}

Akpor, E. D. \& Clever, A. (2016).Media Coverage of Ebola Virus Disease in Nigeria Using Guardian and Punch Newspapers. International Journal of International Relations, Media and Mass Communication Studies.2 (2), 41-50. Retrieved from www.eajournals.org

Clack, T. and M. Brittain (eds) 2007. Archaeology and the Media. Walnut Creek, CA: Left Coast Press.

Danbello, I. A. \& Dakogol, B. J. (2016).The role of indigenous films in preserving culture in $\quad$ Nigeria: An appraisal of Nollywood Home Videos. Retrieved from http:/www.adjournal.net/articles/41/413.pdf

Eck, C.R. (2014). Preserving Heritage: The Role of the Media. In Smith, C. (Ed.) Encyclopedia of Global Archaeology. New York: Springer.

Folorunso, C.A. The Practice of Archaeology in Nigeria, March 2011

Igbinoba, O. A. (2008).Coverage of sexuality issues in the Nigerian print media. Retrieved from www.theses.covenantuniversity.edu.n

Iheanacho, N.N. (2014). Media Role in Cultural Education, Acculturation and Diffusion: An Ambivalence of Plausibility and Dysfunctional Trajectories. The Crab: Journal of Theatre and Media Art. Retrieved from pdfs.semanticscholar.org

Kimbers, Y. (2006). Conservation Archaeology. Unpublished M.A. Seminar Paper, Dept. of Archaeology, Ahmadu Bellow University, Zaria.

McManamon, F. Presenting Archaeology to the Public in the USA. In Stone,P.G. and Molyneaux, B.L. (Eds.). (1994). The Presented Past: Heritage, Museums, and Education. New York: Routledge.

Nwabueze, C., Frank, N. \& Umeora, D. (2015). Nigerian Newspapers' Coverage of Climate Change Issues. European Scientific Journal. Pp.171-184. Retrieved on March 18, 2016 from www.eujournal.org/index

Ogundele, O. (1995). Settlement Archaeology in Nigeria: A Short Note. This is a report sent with a letter of 18th December 1995 by Dr. Ogundele to Department of Archaeology, Okayama University NIIRO Izumi 20th Feb. 1996 - Retrieved from http://www.okayamau.ac.jp/user/arch/news/wac/ogund1e.html

Romanova, P.A., Yakushenkov, N.S. \& Lebedeva, I.V. (2013). Media Coverage of Cultural Heritage and Consumerism in Modern Society. World Applied Sciences Journal. Retrieved from DOI: 10.5829/idosi.wasj.2013.24.01.13178 
Rukya, H.(2016).The Role of Media in Promoting Indigenous Cultural Values: Critical Discourse Analysis. Retrieved from https://www.researchgate.net/publication/305880744

Simon, R.O, \& Ndoma, B. E. (2016). Nigerian Media and Indigenous Cultures Transformation: The Journey So Far. J Mass Communicat Journalism 6: 317. doi: 10.4172/2165-7912.1000317

Stephen, K. (2014). Mass Communication: An introduction to sociology of mass media. Nnewi: Cathcom Press.

Wegdam, L. (2015). Archaeology on Stage, Or Staging Archaeology? A Content Analysis of Documentaries on The National Geographic Channel in 2013. A Bachelor Thesis: ARCH 1043WY, submitted to Archaeological Heritage Management Universiteit Leiden, Faculteit der Archeologie Leiden, 15 June 2015.

William, A. J., Layefa, G. \& Taiwo, A. (2016). The Press and Social Responsibility: Newspaper Coverage of the 2014 Ebola Virus Disease Outbreak in Nigeria. Journal of Humanities and Social Science. 21(6), 0713.Retrieved from www.iosrjournals.org

Wimmer, R. D., \& Dominick, J. R. (2011). Mass media Research: An Introduction. USA: Cengage Learning

Winthrop, R.H. (199). Dictionary of Concepts in Cultural Anthropology. New York: Greenwood Press. 